\title{
Correction to: Semaglutide: Charting New Horizons in GLP-1 Analogue Outcome Studies
}

David M. Williams (D) - Marc Evans

Published online: January 8, 2021

(C) The Author(s) 2020

Correction to: Diabetes Ther

https://doi.org/10.1007/s13300-

020-00917-8

In the original article, the sentence "The primary outcome of 3-point MACE occurred in significantly fewer participants receiving semaglutide (HR 0.79, CI 0.57-1.11)" was published with an error and should be discounted from the review. The authors wish to update this sentence instead to state that "Semaglutide resulted in numerically, albeit not statistically significantly, fewer CV events (HR 0.79, CI 0.57-1.11)".

The original article has been corrected.

Open Access. This article is licensed under a Creative Commons Attribution-NonCommercial
4.0 International License, which permits any non-commercial use, sharing, adaptation, distribution and reproduction in any medium or format, as long as you give appropriate credit to the original author(s) and the source, provide a link to the Creative Commons licence, and indicate if changes were made. The images or other third party material in this article are included in the article's Creative Commons licence, unless indicated otherwise in a credit line to the material. If material is not included in the article's Creative Commons licence and your intended use is not permitted by statutory regulation or exceeds the permitted use, you will need to obtain permission directly from the copyright holder. To view a copy of this licence, visit http:// creativecommons.org/licenses/by-nc/4.0/.

The original article can be found online at https://doi. org/10.1007/s13300-020-00917-8.

D. M. Williams $(\bowtie) \cdot$ M. Evans

Department of Diabetes and Endocrinology,

University Hospital Llandough, Cardiff, UK

e-mail: david.williams@doctors.org.uk 